\title{
INTEGRITAS PENDIDIKAN MENUAI WIRAUSAHA DI ERA PANDEMI DESA BUNTU KARYA KECAMATAN LUWU KABUPATEN PONRANG SELATAN PROVINSI SULAWESI SELATAN
}

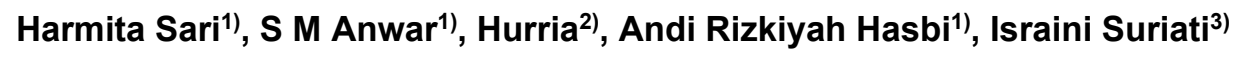 \\ 1)Jurusan Manajemen, Fakultas Ekonomi dan Bisnis, Universitas Muhammadiyah Palopo, Palopo, \\ Sulawesi Selatan, Indonesia. \\ 2) Jurusan Farmasi, Fakultas Kesehatan, Pertanian, dan Kelautan, Universitas Muhammadiyah Palopo, Palopo, \\ Sulawesi Selatan, Indonesia. \\ 3) Jurusan Kebidanan, Fakultas Kesehatan, Pertanian, dan Kelautan, Universitas Muhammadiyah Palopo, Palopo, \\ Sulawesi Selatan, Indonesia. \\ Penulis korespondensi : Harmita Sari \\ E-mail : harmitasari93@gmail.com
}

Diterima 23 November 2020, Direvisi 19 Desember 2020, Disetujui 19 Desember 2020

\begin{abstract}
ABSTRAK
Seminar merupakan salah satu kegiatan yang dapat dilakukan sebagai proses untuk memecahkan suatu masalah, atau proses menemukan solusi yang biasanya diangkat dari hasil sebuah penelitian atau literatur. Berdasarkan hasil observasi dan wawancara yang dilakukan di desa Buntu Karya dengan melihat pendidikan dari masing masing pemuda dan masyarakat, relatif masih kurang dikarenakan kurangnya minat masyarakat akan pendidikan itu sendiri atau masyarakat lebih tertarik untuk bekerja baik bertani maupun pekerjaan lainnya. Dengan melihat adanya berbagai potensi hasil alam yang ada di Desa Buntu Karya penulis mengangkat seminar kewirausahaan dengan maksud agar kiranya warga atau masyarakat dapat mengolah atau memanfaatkan hasil alamnya dengan baik. Karena adanya pandemi sampai saat ini, berbagai dampak yang terjadi salah satunya adalah dampak kecemasan terhadap kesehatan, bagaimana cara menjaga dan menempatkan diri ketika berada di keramaian dengan mematuhi protokol kesehatan.
\end{abstract}

Kata kunci : integritas pendidikan; wirausaha; covid-19; desa buntu karya

\begin{abstract}
The seminars is one of the activities that can be carried out as a process to solve a problem, or the process of finding a solution which is usually based on the results of a study or literature. Based on the results of observations and interviews conducted in Buntu Karya Village by looking at the education of each youth and community, it is relatively still lacking due to the lack of public interest in education itself or the community is more interested in working both farming and other jobs. By looking at the various potentials of natural products in Village Buntu creation Village, the author raises an entrepreneurship seminars with the intention that residents or the community can process or make good use of natural products. Because of the existence of pandemic until now, various impacts have occurred, one of which is the impact of anxiety on health, how to guard and place oneself when in a crowd by complying with health protocols.
\end{abstract}

Keywords : education integrity; entrepreneurship; covid-19; buntu karya village

\section{PENDAHULUAN}

Desa Buntu Karya dimekarkan pada tahun 2008, pecahan dari dari dua wilayah yaitu Kariako dan Buntu Nanna. Desa Buntu Karya adalah salah satu dari 5 Desa yang masuk ke dalam wilayah Kecamatan Ponrang Selatan. Desa Buntu Karya memiliki luas wilayah kurang lebih 8,9 km2. Desa Buntu Karya terletak di bagian Selatan Kabupaten Luwu dengan batasbatas sebagai berikut, Sebelah utara Desa Olang, Sebelah Timur Desa Desa Olang, Sebelah Selatan Desa Paccerakang, Sebelah Barat Kel. Padang Subur dan Desa Buntu Batu
(Badan pusat Statistik Kabupaten Luwu, 2018). Desa Buntu Karya berada pada posisi strategis yang dilalui oleh jalan Nasional Lintas Palopo-Makassar. Bentuk Morfologi desa Buntu Karya dari bagian Timur dan Utara berupa dataran rendah dan semakin keselatan dataran bergelombang dan perbukitan. Orbitasi dari pusat pemerintahan desa ke lbu Kota Kecamatan sekitar $4 \mathrm{Km}$ dengan waktu tempuh sekitar 10 menit sedangkan ke lbu Kota Kabupaten sekitar $20 \mathrm{Km}$ dengan waktu tempuh sekitar 30 menit. Desa Buntu Karya terbagi atas 4 wilayah Pemerintahan (Dusun) 
anatara lain, yaitu Dusun Kariako, Dusun Rewang, Dusun Sompu dan Dusun Kaccanning (Badan pusat Statistik Kabupaten Luwu, 2019a).

Sarana kesehatan yang terdapat di Desa Buntu Karya yaitu 1 Unit Pustu di Dusun Rewang. Desa Buntu Karya sudah dijangkau oleh jaringan PLN untuk kebutuhan penerangan energi listrik. Penduduk Desa Buntu Karya belum mengakses air bersih melalui sarana perpipaan. Karena sarana perpipaan (PDAM) belum memasuki wilayah desa, sehingga masyarakat hanya menggunakan sumur buatan. Kondisi Penduduk Desa Buntu Karya terdiri atas 670 Kartu Keluarga dengan total jumlah jiwa adalah 3225 orang, yang terdiri dari 1583 laki-laki dan 1642 perempuan (Badan pusat Statistik Kabupaten Luwu, 2019b).

Mata pencaharian pokok pada umumnya penduduk Desa Buntu Karya adalah bertani. Hanya sebagian kecil bekerja di bidang lain. Selain bertani, Mata Pencaharian lainnya yaitu sebagai PNS, Pedagang, Buruh, Tukang Batu, Sopir Mobil, serta ada pula bekerja sebagai Peternak, Hewan ternak yang dipelihara Ayam, dan Kambing.

Desa Buntu Karya dilalui oleh jalan kecamatan yang menghubungkan antara Desa Buntu Karya, Desa Buntu Kamiri dan Desa Olang. Jalan ini merupakan jalan utama untuk menuju ke Kantor Camat, Puskesmas, Pasar Kecamatan yang terletak di Desa Pattedong (Badan pusat Statistik Kabupaten Luwu, 2019c).

Di sepanjang jalan ini juga terdapat beberapa cabang jalan yang merupakan akses ke Jalan kampung dan jalan tani. Jalan poros kecamatan, jalan kampung dan jalan tani ini diharapkan dapat menjadi penunjang utama dalam berbagai aktifitas masyarakat, khususnya dalam kegiatan perekonomian penduduk.

Beberapa penduduk memanfaatkan jasa sepeda motor untuk mengangkut penumpang dan berbagai jenis barang dalam jumlah terbatas. Untuk keperluan pengangkutan rombongan dan barang dalam jumlah banyak digunakan truk. Truk ini biasa juga digunakan untuk mengangkut bahan bangunan dan ternak besar (sapi dan kerbau). Desa Buntu Karya sudah dijangkau oleh jaringan PLN untuk kebutuhan penerangan dan lain-lain Penduduk Desa Buntu Karya belum mengakses air bersih melalui sarana perpipaan. Karena sarana perpipaan PDAM belum memasuk wilayah desa, sehingga masyarakat hanya menggunakan sumur buatan (Laporan Kinerja Instansi Pemerintah Kabupaten Luwu Dinas Pendidikan, 2018). Sebagai pemenuhan sarana pendidikan. Di Desa Buntu Karya terdapat Taman Kanak-Kanak yang berada di Dusun Rewang dan Dusun Kariako, Sekolah Dasar yang berada di Dusun Kariako, dan Sekolah Luar Biasa (SLB) di Dusun Rewang (Laporan Kinerja Instansi Pemerintah Kabupaten Luwu Dinas Pendidikan, 2019).

Untuk meningkatkan kesehatan ibu dan anak balita di Desa Buntu Karya terdapat 1 unit Puskesmas Pembantu (PUSTU) sebagai pemenuhan sarana kesehatan desa di Dusun Rewang. Khusus untuk potensi sumberdaya alam, ada beberapa hal yang sangat mendukung pendapatan masyarakat, yakni : Tanah pertanian di Desa Buntu Karya cukup subur untuk ditanami berbagai jenis tanaman. Beberapa hasil pertanian di Desa Buntu Karya antara lain Padi, pisang, Cacao, Jagung, dan Nilam. Di samping bertani, penduduk Desa Buntu Karya juga memelihara ternak seperti ayam, waled dan Kambing. Metode pemeliharaan masih menggunakan cara tradisional, yakni digembalakan atau dikandangkan. Minat masyarakat untuk memelihara ternak cukup besar, namun karena keterbatasan modal dan kurangnya pengetahuan dan bimbingan, sehingga masih dikelola dalam jumlah yang terbatas.

Terdapat beberapa permasalahan yang muncul pada tiap bidangnya yang membuat terhambatnya aktivitas warga. Permasalah yang ada diuraikan sebagai berikut: Kesuburan tanah, kualitas dan kuantitas sumber air menurun, serta rawan terjadi pencemaran dan polusi udara di Desa Buntu Karya Lingkungan dan sumberdaya alam di Desa Buntu Karya sudah dirasakan mengalami penurunan kualitas 10 tahun terakhir. Lahan pertanian makin tidak produktif. Ketergantungan pupuk kimia dan pestisida semakin tinggi, yakni rata-rata 6 - 8 sak dan minimal 1 liter herbisida per hektar. Pola ini mengalami peningkatan setiap musim. Sumber mata air juga mengalami hal serupa. Beberapa titik mata air menghilang dan kebutuhan air bersih serta kebutuhan untuk pertanian makin berkurang. Kualitas air sungai yang melintas di dalam lembang dinilai menurun. Ekosistemnya mengalami penurunan fungsi dan kehilangan sejumlah spesies.

Separuh dari dua sisi sungai terjadi erosi dan mengalami pendangkalan. Sungai ini sangat vital bagi pertanian khususnya bila musim hujan tidak menentu. Kekayaan sungai ini dulunya menjadi sumber protein bagi masyarakat. Kemarau, polusi, debu menjadi keluhan warga. Tingginya penggunaan pestisida sistemik dan sistem pembakaran limbah pertanian menjadi potensi 
meningkatnya pencemaran karbondioksida (CO2).

Desa Buntu Karya selain dikenal dengan penghasilannya pertanian nya, juga dikenal dengan hasil ternak ayam nya. Dimana, di desa Buntu Karya terdapat dua kandang pemeliharaan ayam potong yaitu berada di dusun kaccaning yang masih beroperasi hingga saat ini dengan perkiraan penghasilan kotor sekitar kurang lebih 5 juta per/bulan, dan juga ada di dusun Sompu tetapi, sudah tidak beroperasi seperti biasanya dimana kendala nya yaitu, tidak ada modal perbaikan kandang dan juga tenaga penjagaan kandang tersebut.

Sumber daya alam desa Buntu Karya yang cukup berpotensial untuk meningkatkan ekonomi dari sektor pertanian, perkebunan dan peternakan menjadi salah satu sumber utama penghasilan masyarakat di desa Buntu Karya. Hasil produksi alam yang melimpah tidak diikuti dengan pola dan jangkauan pemasaran hasil yang lancar membuat masyarakat sangat tergantung dengan tekanan harga lokal. Sehingga hasil produksi petani baik dari padi maupun sawah dijual pada pedagang pengumpul yang menerapkan harga jual dibawah dari harga yang ada di pasaran umum. Selain itu, untuk menjual hasil pertanian dan memenuhi kebutuhan sehari-hari, masyarakat desa Buntu Karya melakukan transaksi di pasar terdekat di ibukota kecamatan Ponrang Selatan yang di adakan dua kali seminggu. Sementara persoalan utama yang dihadapi oleh pedagang adalah kekurangan modal usaha. Bagi pedagang/warung di desa Buntu Karya, modal usaha sangat menentukan perkembangan usahanya dalam pembelian dan pengangkutan barang dagangannya.

Berdasarkan hasil pengamatan maka terdapat beberapa permasalahan pokok yang dihadapi oleh masyarakat di kecamatan Ponrang Selatan yaitu minimnya pengetahuan tentang motivasi Pendidikan kewirausahaan dan covid-19 bagaimana sulitnya menghadapi permasalahan terutama dikalangan ibu-ibu bagaimana cara untuk mendampingi anakanak belajar secara virtual dan juga cara menghadapi situasi di era pademi seperti saat ini (Maryani, 2020), hal-hal apa saja yang dapat dilakukan walaupun hanya di rumah saja ada banyak hal yang dapat di lakukan maka dari itu kami berinisiatif untuk melakukan seminar ini agar dapat menambah pengetahuan dan wawasan masyarakat di era pandemi (Indra Djati Sidi, 2003). Adapun tujuan dari seminar ini yaitu meningkatkan atau mengubah paradigma-paradigma masyarakat tentang pentingnya pendidikan dan dapat berwirausaha di tengah pandemi covid-19 dengan memanfaatkan berbagai potensi atau sumber daya alam yang apa pada Desa Buntu Karya dengan tetap mematuhi protokol kesehatan 3M yakni Memakai Masker, Mencuci Tangan, dan Menjaga Jarak Fisik (Arifa, 2020).

\section{METODE PELAKSANAAN \\ Tempat dan Waktu}

Pelaksanaan program kegiatan Pengabdian Masyarakat dilaksanakan di Desa Buntu Karya Kecamatan Ponrang Selatan Kabupaten Luwu Provinsi Sulawesi Selatan. Jarak dari Desa Buntu Karya Ibukota Kabupaten Luwu Utara yaitu 60 km. Jumlah Dusun di Desa Buntu Karya sebanyak 4 Dusun yakni Dusun Kariyako, Dusun Sompu, Dusun Rewang dan Dusun Kaccaning. Program ini dilaksanakan pada 08-9 Oktober 2020. Khalayak Sasaran. Adapun khalayak yang menjadi sasaran pada kegiatan Pengabdia Masyarakat ini yaitu kelompok Ibu-ibu PKK, pemuda dan warga di Desa Buntu Karya Kecamatan Ponrang Selatan kabupaten Luwu Provinsi Sulawesi Selatan. Yang berjumlah 50 orang. Angka tersebut berdasarkan jumlah peserta yang hadir pada saat seminar motivasi pendidikan, seminar kewirausahaan, dan seminar covid-19 di Desa Buntu Karya Kecamatan Ponrang Selatan Kabupaten Luwu Provinsi Sulawesi Selatan.

\section{Metode Pengabdian}

Adapun pelaksanaan metode pelaksanaan kegiatan pengabdian yang dilakukan, yaitu:

a. Persiapan dan Koordinasi

Pelaksanaan program kegiatan Pengabdian Masyarakat dimulai dari tahap persiapan dan koordinasi yakni persiapan rencana program kegiatan Pengabdian Masyarakat, rapat kelompok Pengabdian Masyarakat dan pembagian tugas dari kordinator masing-masing anggota kelompok (Eti Rockhaety, 2005).

b. Penyuluhan

Tahap selanjutnya dari pelaksanaan program kegiatan Pengabdian Masyarakat yaitu penyuluhan kegiatan yang dilaksanakan pada seminar rencana program Pengabdian Masyarakat pada tanggal 3 Juli 2018.

c. Demonstrasi

Tahap selanjutnya dari pelaksanaan program kegiatan Pengabdian Masyarakat yaitu tahap demonstrasi yang terbagi menjadi 3 kegiatan yaitu sebagai berikut:

c.1Mempersiapakan alat, bahan, 
peralatan dan perlengkapan yang digunakan dalam seminar, yaitu:

1) Alat
a. Wadah
pembuatan
handsenitaizer b. Sendok untuk pengadukan

2) Bahan
a. Alkohol $70 \%$
b. Glisetin
c. Aqua
d. Botol $100 \mathrm{ml}$

3) Peralatan
a. Gedung seminar yang bertempatkan di SD Kariyako
b. Pemateri
c. Sound sistem
d. LCD

4) Perlengkapan
a. Persuratan
b. Spanduk
c. Laptop
d. Buku
e. Bulpoin

c.2Metode pelaksanaan seminar, yaitu:

a. Masing-masing pemateri diberikan batas waktu tertentu untuk memaparkan materinya.

b. Audiens diberikan kesempatan untuk mengajukan pertanyaan kepada masing-masing pemateri.

\section{Indikator Keberhasilan}

Indikator keberhasilan pelaksanaan kegiatan Pengabdian Masyarakat, yaitu 1). Meningkatkan kesadaran terhadap masyarakat akan pentingnya pendidikan, kewirausahaan dalam pademi saat ini. 2).Terbantunya masyarakat dalam menambah pengetahuan dalam mendidik dan berwirausaha di masa pandemi. 3). Masyarakat mampu mengamalkan pembelajaran yang diberikan oleh pemateri. 4). Masyarakat dapat menerapkan teori-teori yang diberikan dengan baik. 5). Pembelajaran terhadap orang tua dan anak secara efektif (Aritonang, 2013). Penentuan kriteria penilaian keberhasilan target luaran, sebagai berikut:

1. Nilai 20-39 (Terkategori Kurang Terampil)

2. Nilai 40-59 (Terkategori Cukup Terampil)

3. Nilai 60-79 (Terkategori Terampil)

4. Nilai $>80$ (Terkategori Sangat Terampil)

Metode evaluasi dilakukan dengan dua tahapan. Tahapan evaluasi pertama akan dilaksanakan pada awal kegiatan program Pengabdian Masyarakat dengan melakukan monitoring internal pada rangkaian kegiatan pelatihan dan penyuluhan (Sarwoko, 2011).

Sedangkan, untuk tahapan evaluasi yang kedua akan dilaksanakan pada akhir kegiatan program Pengabdian Masyarakat, kegiatan dinyatakan tercapai apabila permasalahan yaitu untuk aspek produksi yang terdiri dari (1) Pemanfaatan sumber daya yang belum optimal; (2) Minim pengetahuan dalam mengolah bahan handsenitaizer; dan (3) Kurangnya pengetahuan orang tua terhadap minimnya pendampingan dan pembelajaran sistem online atau daring. Keberhasilan kegiatan dilakukan evaluasi kegiatan dengan membanding hasil pre-test dan post test (Edward Sallis, 2006).

\section{HASIL DAN PEMBAHASAN}

Hasil yang telah dicapai pada Program kerja Pengabdian Masyarakat yang dilaksanakan di Desa Buntu Karya Kecamatan Ponrang Selatan Kabupaten Luwu, sebagai berikut:

\section{A. Observasi}

Observasi dilakukan beberapa tahap, yaitu dimulai dengan melakukan pendekatan kepada masyarakat mengenai kegiatan Program Pengabdian Masyarakat ini, khususnya dalam hal memotivasi masyarakat akan pentingnya pendidikan, meningkatkan atau mengubah paradigma- paradigma masyarakat tentang pentingnya pendidikan dan dapat berwirausaha di tengah pandemi covid19 dengan memanfaatkan berbagai potensi atau sumber daya alam yang ada pada Desa Buntu Karya dengan tetap mematuhi protokol kesehatan 3M yakni Memakai Masker, Mencuci Tangan, dan Menjaga Jarak Fisik (Atsani, 2020).

B. Penyuluhan

Penyuluhan mengenai pentingnya pengetahuan untuk mengoptimalkan pemanfaatan sumber daya yang ada di masa pandemi, dengan beberapa tahap:

1. Diskusi tim dengan masyarakat/ Ibu-ibu PKK Desa Buntu Karya tentang materi- materi semiar yang akan disajikan dan yang dibutuhkan.

2. Kesepakatan tim dan masyarakat Ibu-ibu PKK Desa Buntu Karya dalam menentukan waktu dan tempat pelaksanaan seminar motivasi.

3. Penyusunan jadwal pelatihan yang dibutuhkan dan melakukan penyuluhan mengenai pentingnya dunia pendidikan dan pemanfaatan sumber daya yang ada dimasa pandemi ini.

Proses observasi hingga Penyuluhan terjadi selama 1 bulan secara intensif memberikan pendekatan dan pemahaman 
kepada pemuda ibu-ibu dan seluruh masyarakat mengenai seminar motivasi baik informasi akan pentingnya dunia pendidikan serta pemanfaatan berbagai hasil alam yang ada di desa Buntu Karya dan tata cara pembuatan handsenitaizer serta bagaimana cara mematuhi protokol kesehatan di era pademi ini. Pelaksanaan pada tanggal 8-9 Oktober 2020 yang dihadiri oleh 50 warga desa Buntu Karya. Penyuluh pada seminar ini yaitu, Harmita Sari, S.Pd., M.Pd sekaligus dosen pembimbing KKN-PPM kerja sosial sebagai pemateri pertama yang membawakan materi motivasi pendidik dengan \#Belajar sepanjang hayat, pemateri kedua yaitu Andi Rizkiyah Hasbi,S,Tt., M.Si membawakan materi menumbuhkan jiwa kewirausahaan, dan pemateri ketiga Apt. Hurria, S.Farm., M.Sc membawakan materi tentang Covif-19.

\section{Demonstrasi}

Kegiatan seminar motivasi pendidikan dengan \#belajar sepanjang hayat bertujuan untuk memotivasi orang tua dan anak tidak ada batasan untuk belajar hingga akhir hayat, dengan seminar kewirausahaan mengajarkan bagaimana cara pemanfaatan kotoran hewan ternak dan buah-buahan dan sayuran yang sudah tidak layak konsumsi di olah menjadi pupuk (Utomo, Mashudi, dan Nuraini, 2014). Sedangkan, seminar Covid-19 mengajarkan bagaimana cara menjaga diri dan mematuhi protokol kesehatan di era pademi ini dan juga mempraktikkan pembuatan handsenitaizer dengan harga yang terjangkau dibanding yang dijual di pasaran. Berikut tampilan gambar beberapa kegiatan yang dilakukan dalam proses pengabdian: (1) foto pemateri bersama masyarakat dan mahasiswa; (2) foto pemateri pertama, menjelaskan tentang motivasi pendidikan, tujuannya agar masyarakat selalu bersemangat mencari ilmu sampai akhir hayat, di tengah pandemi; (3) foto pemateri ke-2 menjelaskan tentang pemanfaatan limbah menjadi pupuk sehingga menambah nilai jual; (4) foto pemateri ke-3 menjelaskan tentang bahaya Covid-19, tips dan trik gaya hidup sehat serta praktik pembuatan handsenitaizer; dan (5) foto penyerahan ucapan terima kasih dari masyarakat ke pemateri berupa sertifikat.

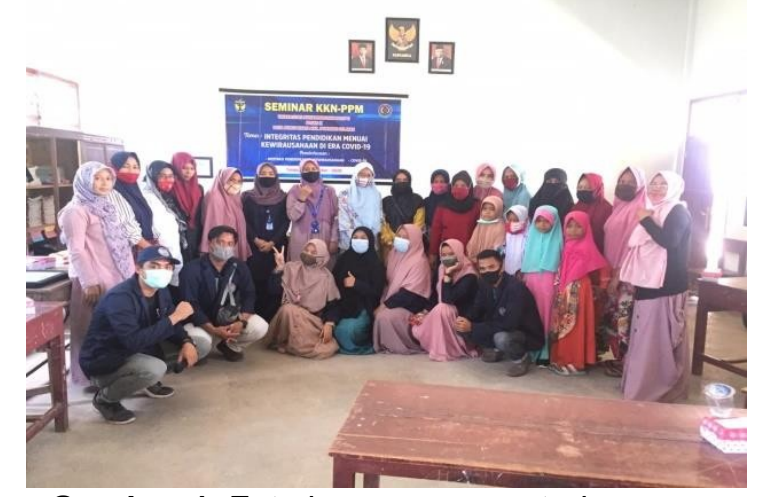

Gambar 1. Foto bersama pemateri, warga, dan mahasiswa KKN

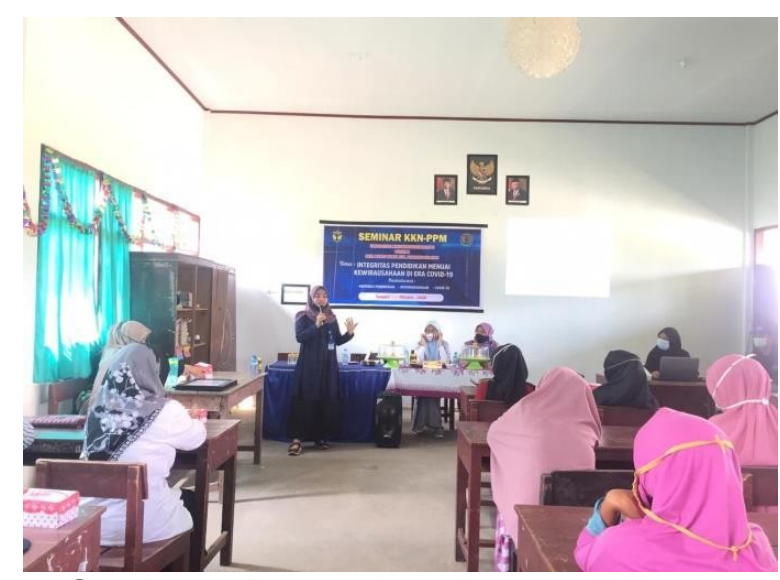

Gambar 2. Pemateri seminar pendidikan \#Belajar sampai akhir hayat 


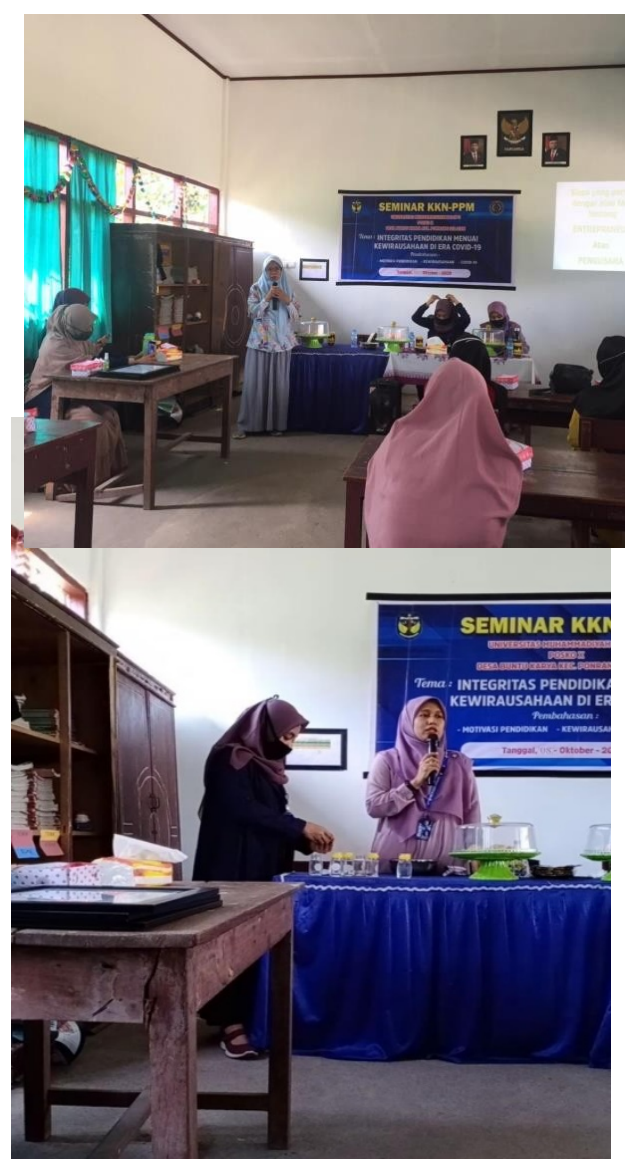

Gambar 4. Pemateri Covid-19

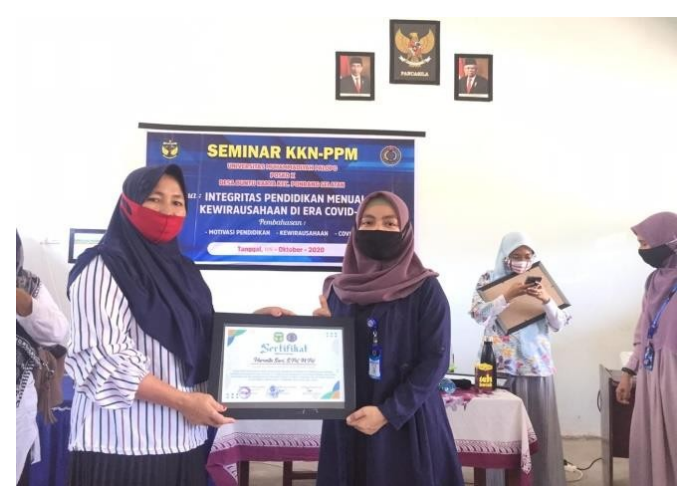

Gambar 5. Penyerahan sertifikat kepada pemateri

\section{Keberhasilan Kegiatan}

Evaluasi keberhasilan kegiatan program kerja Pengabdian Masyarakat kerja sosial yaitu dengan membandingkan hasil penilaian dari serangkaian kegiatan yang telah di seminarkan telah berjalan sebagaimana mestinya, dimana aktifnya pendampingan pembelajaran online dan juga telah di manfaatkan kotoran ternak, sayuran dan buah yang tidak layak komsumsi diolah menjadi pupuk, dengan meningkatnya dan terubahnya paradigma-paradigma masyarakt tentang pentingnya menjaga kesehatan di tengah pandemi covid-19.

\section{SIMPULAN}

Kegiatan pelaksanaan Pengabdian Masyarakat kerja sosial melalui seminar motivasi pendidikan, kewirausahaan dancovid19 dengan tema "Integritas Pendidikan Menuai Wirausaha Di Era Pandemi " di desa Buntu Karya kecamatan Ponrang Selatan Kabupaten Luwu Provinsi Sulawesi Selatan terlaksana dengan baik hasil dari kegiatan mampu memberikan dampak baik terhadap peningkatkan atau mengubah paradigmaparadigma masyarakat tentang pentingnya pendidikan dan dapat berwirausaha di tengah pandemi covid-19 dengan memanfaatkan berbagai potensi atau sumber daya alam yang apa pada Desa Buntu Karya dengan tetap mematuhi protokol kesehatan $3 \mathrm{M}$ yakni Memakai Masker, Mencuci Tangan, dan Menjaga Jarak Fisik.

\section{UCAPAN TERIMA KASIH}

Penulis ucapkan terima kasih kepada Rektor dan ketua LPPM Universitas Muhammadiyah Palopo yang telah mewadahi penulis dalam melaksanakan pengabdian masyarakat. Terima kasih kepada Aparat Desa, Ibu-ibu PKK dan seluruh warga desa Buntu Karya Kecamatan Ponrang Selatan Kabupaten Luwu Provinsi Sulawesi Selatan yang telah memberikan kerja sama yang baik sehingga program pegabdian masyarakat ini telah selesai.

\section{DAFTAR RUJUKAN}

Arifa, F. . (2020) Tantangan Pelaksanaan Kebijakan Belajar Dari Rumah Dalam Masa Darurat Covid -19.

Aritonang, K. T. (2013) 'Pengintegrasian Pendidikan Kewirausahaan melalui Pembelajaran Terpadu Berbagai Disiplin IImu', Jurnal Pendidikan Penabur, 12(21), pp. 63-77.

Atsani, L. G. M. Z. (2020) 'Transformasi Media Pembelajaran Pada Masa Pandemi Covid-19', Jurnal Studi Islam, 1(2), pp. 44-54.

Badan pusat Statistik Kabupaten Luwu (2018) Kecamatan Ponrang Selatan dalam Angka, Luwu: Badan Pusat Statistik Kabupaten Luwu.

Badan pusat Statistik Kabupaten Luwu (2019a) Kecamatan Ponrang Selatan dalam Angka, Luwu: Badan Pusat Statistik Kabupaten Luwu.

Badan pusat Statistik Kabupaten Luwu (2019b) Kecamatan Ponrang Selatan dalam Angka, Luwu: Badan Pusat Statistik Kabupaten Luwu. 
Badan pusat Statistik Kabupaten Luwu (2019c) Kecamatan Ponrang Selatan dalam Angka, Luwu: Badan Pusat Statistik Kabupaten Luwu.

Edward Sallis (2006) Total Quality Manajemen In Education. Edited by Ali Bahasa Ahmad Ali Riadi. Yogyakarta: IRCiSoD.

Eti Rockhaety, dkk (2005) Sistem Informasi Manajemen Pendidikan. Jakarta: Bumi Aksara.

Indra Djati Sidi (2003) Menuju Masyarakat Belajar. Jakarta: Logos.

Laporan Kinerja Instansi Pemerintah Kabupaten Luwu Dinas Pendidikan (2018).

Laporan Kinerja Instansi Pemerintah Kabupaten Luwu Dinas Pendidikan (2019).

Maryani, K. (2020) 'Penilaian dan Pelaporan Perkembangan Anak Saat Pembelajaran di Rumah di Masa Pandemi Covid-19', Murhum, 1(2), pp. 41-52.

Sarwoko, E. (2011) 'Kajian Empiris Entrepreneur Intention Mahasiswa', Jurnal Ekonomi Bisnis, (2), pp. 127135.

Utomo, B. B. and Mashudi dan Nuraini (2014) 'Pengaruh Pendidikan Kewirausahaan dalam keluarga dan di Sekolah terhadap Minat Berwirausaha', Jurnal Pendidikan dan Pembelajaran, 3(4), pp. $1-15$. 